\title{
Božo Repe \\ The Tito-Stalin Conflict: Yugoslavia as the Westernmost Part of the Eastern World
}

After the Communist Party (or the Liberation Front in Slovenia) assumed power and crushed its non-party opposition at the end of World War II, the focus of political dissension in Yugoslavia and Slovenia shifted to the factions within the Communist Party (renamed the League of Communists in 1952). Before the mid-1980s, there was no organised opposition in Slovenia. The only exceptions were the Catholic Church, with which the authorities started searching for common ground in the second half of the 1950s, finally achieving a bearable modus vivendi in the 1960s; and the intellectual opposition, centred around individual journals, whose freedom was determined by the current mood and power relations at the top. From the late 1940s to the early 1980s, there were three major instances of score-settling during the Pan-Yugoslav campaigns and purges, which also reached Slovenia and, at the same time, went beyond mere inner-party score-settling: The Cominform, Đilasism and party "Liberalism".

The Cominform (Communist Information Bureau) was established on 30 September 1947 in Szklarska Poręba, Poland. The session was attended by the communist parties of the Soviet Union, Romania, Bulgaria, Hungary, Czechoslovakia, Poland, Albania, France, Italy, and Yugoslavia. After the session, a communiqué was issued which stated that the tasks of the Cominform were to organise an exchange of experiences between the communist parties and, should the need arise, coordinate their activities based on the spirit of unity, and that it had been decided at the session that the Information $\mathrm{Bu}-$ reau would publish its own periodical with an editorial office based in Belgrade. The actual purpose of this consultation was to strengthen the influence of the Soviet Union in East European countries and in Yugoslavia, while using the biggest Western communist parties (of Italy and France) to influence the turbulent, almost revolutionary conditions in those two countries. This policy soon began to conflict with the policy of the CPY, which was - apart from the VKP(b) [All-Russian Communist Party (Bolshevik)] - the 
most powerful communist party in the socialist camp, and which had experienced an authentic revolution under conditions and a setting that greatly differed from that of the Russian Revolution of 1917. Because of this conflict, Yugoslavia found itself in almost total international isolation and on the brink of war. Opting for the Cominform was considered treason by the Yugoslav leadership, who used Stalinist methods to fight the Cominform. While they were settling scores with actual or alleged Cominformists, around 60,000 people in Yugoslavia were expelled from the Party, and 16,312 people (including high-ranking personnel - deputies, ministers, officers, etc.) were given various sentences, including imprisonment at special isolation camps on the islands of Goli Otok and Grgur and elsewhere. Under the guise of "re-education", prisoners were subjected to various forms of physical and psychological torture; many did not survive. The state further strengthened its repressive apparatus and various forms of exerting pressure while the leadership carried out accelerated collectivisation in the countryside to prove that, despite the criticism of the Soviet Union, it was "building" socialism and was on the "right path". Around 5,000 Yugoslav citizens, who had fled their home country acted against it in various propaganda centres in East European socialist countries. ${ }^{1}$

Đilasism was named after Milovan Đilas, one of the four most powerful post-war Yugoslav politicians (along with Tito, Ranković and Kardelj). During the war, he exerted revolutionary terror in Montenegro (the so-called second stage of the revolution) and was a sworn Stalinist in the first post-war years. However, in the early 1950s he was the main author of the resolutions for the Sixth Congress of the CPY at which the CPY renounced its role of a state party (though only formally) and renamed itself the League of Communists. In late 1953, he wrote a number of articles in Borba and Nova misao, in which he criticised the bureaucratism within the Party and in society, the Bolshevist party model, and the altered revolutionary morality. His rather confused and contradictory ideas advocated a two-party socialist system (the League of Communists was to be "opposed" by the Socialist Alliance). At the third plenum of the CC of the CPY in January 1954, his ideas were labelled "anarcho-liberalist" and "revisionist"; he was expelled from political life and later received prison sentences on several occasions. He spent a total of nine years in prison, two and a half of which in solitary confinement. He was released in December 1966, after which he emigrated and spent his time writing and lecturing in Western countries, mostly in the USA. He returned to Yugoslavia in the 1980s and died there. Đilas never attempted to create his own faction within the League of Communists nor did he have an organised network of followers; nevertheless, from the mid-1950s to the early 1960s, "Đilasism" was the worst negative ideological label, second only to the Cominform, to be given to opponents of the official policy. His real or alleged followers were then crushed politically (deposings, transfers, and the like). ${ }^{2}$

1 Lešnik, Informbiro, p. 369.

2 For more see in: Perović, Dominantna i neželjena. 
Party Liberalism was a heterogeneous movement, which emerged at the end of the 1960s and early 1970s in Slovenia, Serbia and Croatia (and partly in Macedonia and Bosnia and Herzegovina), and which was connected with individual influential younger-generation politicians (Latinka Perović and Marko Nikezić in Serbia, Miko Tripalo and Savka Dabčević-Kučar in Croatia, and Stane Kavčič in Slovenia). It was the result of the changes in Yugoslav society from the mid-1960s onwards (economic reform; the admission that the national issue had not been solved once and for all; the political removal of Aleksandar Ranković as Tito's number two and as an agent of repression and an advocate of centralisation). These changes were accompanied by strong national pressures and outbreaks of nationalism, e.g. in Kosovo in 1968 and in Croatia in 1971; by intellectual dissent (expressed through the protests of intellectuals in the 1960s and through student demonstrations in 1968); in part, these changes were also influenced from abroad (the "Prague Spring" and the occupation of Czechoslovakia). In Slovenia, Liberalism aimed at greater political pluralism among and in the existing political organisations and strove for the continuation of economic reforms and the market economy concept with social correctives provided by the state. It insisted on greater Slovenian independence within the federation, including the right to establish direct international contacts and take out international loans, and the participation fee principle in sustaining the federation. It strove for greater independence in the defence policy (Republican Territorial Defence, the right to serve in the army in one's home republic or, if that were impossible, in nationally homogeneous units, and the right to use one's mother tongue in the army). The economic concept envisaged the development of propulsive industries (commerce, banking, transport, tourism, service activities, consultancy, engineering, and also information and computer science, in terms of development). Slovenia was to become a bridge between Eastern and Western countries, while modelling its economy mainly after the West. Energy-wise, it was to work towards the development of "clean" energies (oil, gas, nuclear power). Administratively speaking, it was to be polycentric, but with a uniform and centrally governed education system, health care, cultural, research and scientific activity, and tax policy. In the early 1970s, Tito and the more orthodox movement in the League of Communists crushed the leading Liberal politicians (in Slovenia, around 400 followers of Liberalism, mostly economists, were deposed); they began deviating from the idea of a market economy (and opted for the so-called negotiated economy), while the outlined changes in international relations were kept and institutionalised in the Constitution of $1974 .^{3}$

In Slovenia, the Cominform was often discussed as a social problem in journalism, literature and historiography, though in a rather biased manner until the early 1980s. The basic premise was that this conflict was merely a logical continuation of previous conflicts, allegedly brought on by the fact that during the war the Yugoslav party had 
started down an original path towards socialism. The settling of scores, the issue of the falsely accused, and the suffering of prisoners remained "taboo topics". In the early 1980s, the first influential literary works were written on the topic, and historiography abandoned the previous claims that Yugoslav Communism had been different in the first post-war years, and started advocating the premise that this conflict was precisely why they started abandoning Soviet-modelled administrative socialism and searching for an alternative path (of self-management). Such conflicts can be dated back to the war. The USSR had subordinated its actions to its relationships with the allies and it demanded that the liberation movement in Yugoslavia do the same. Hence, it rejected all "premature" revolutionary measures, as well as measures directed against the government in exile and King Peter (e.g. the issue of proletarian brigades or their insignia - the hammer and sickle; the issue of implementing the so-called second stage of the revolution; the issue of establishing AVNOJ in Bihać as a political but not an authoritative body; something similar could be said for the second AVNOJ session of which the USSR was informed just before it began). The Yugoslav leadership also quietly resented the Soviet one for providing much more modest aid than the West during the war (until the autumn of 1944, when the USSR equipped twelve infantry and two aviation divisions of the Yugoslav Army), and that until the spring of 1942 Moscow praised Draža Mihailović as the leader of the resistance in Yugoslavia. After the war, protests were triggered by Tito's speech in Ljubljana in May 1945 in which he said that Yugoslavia would not be small change in a bargain between the great powers, referring to the agreement concluded during the war between the Allies, which stated that Austria would be restored to its pre-1938 borders, and which dealt a blow to Yugoslav demands to change the borders in Carinthia; then there was the issue of Trieste, in which the USSR did not want to risk a straining of relations (and potentially a new war); and the issue of occasional inconsistent support given to Yugoslav demands by the USSR at the Paris Peace Conference. Conflicts also arose because of the conduct of the Red Army during military operations on Yugoslav territory (rapes, thefts, violence against the population), but these were covered up until the Cominform conflict. In the first post-war years, economic relations were especially problematic: unequal exchange, the establishment of mixed companies that were more beneficial to the Soviet Union, pressures to establish a mixed Soviet-Yugoslav bank, etc.

However, these conflicts had not eroded the relations between the two parties and countries, generally speaking; the closest relations with the first land of socialism were never questioned and the West believed that Yugoslavia was the most loyal follower of the Soviet Union. The last influential work, which was based on the viewpoint that the different nature of Yugoslavia was the cause of the conflict with Stalin, was the book by Vladimir Dedijer, titled The Battle Stalin Lost (1969). ${ }^{4}$ Afterwards, critical judgement 
gradually strengthened; a more prominent milestone was the period after Tito's death, although in the first half of the 1980s certain historians in Yugoslavia and Slovenia still argued that self-management had not started after the Cominform conflict and as an alternative to the Soviet model, but (as the leading Slovenian politician Edvard Kardelj also claimed) already during the war. ${ }^{5}$ In addition to a number of articles in scientific journals, among the books that adopted a more critical approach in the second half of the 1980s were books by Jože Pirjevec, Dušan Bilandžić and Darko Bekić. ${ }^{6}$ In the late 1980s, the then most prominent expert on contemporary Yugoslav history Branko Petranović wrote that "Yugoslavia remained a communist country even after 1948,"7 and that the Yugoslav theoretical thought ("previously paralysed by Stalinist ideological totalitarianism") started focusing on "discovering new paths to revolution" only after the Cominform conflict. ${ }^{8}$ The second half of the 1980 s was also characterised by analyses conducted by the then prominent Yugoslav political scientists and sociologists (Zagorka Golubović, Laslo Sekelj, Vojislav Koštunica and others), who attempted to prove with considerable precision and at a theoretical level in what ways the Yugoslav model had remained loyal to the Soviet (Bolshevist) version of socialism even after the Cominform conflict, and where the main differences lay.

In Slovenia, very few people openly supported the Cominform, which is why we cannot speak of an organised Cominform opposition. There was no danger of a "fifth column" in the event of a Soviet attack, in contrast to the traditionally Russophile regions of Yugoslavia. However, the lists of the State Security Administration (UDBA) contained the names of many people who criticised the authorities for various reasons. Because the term Cominformist became a synonym for an internal enemy of the state, such critics of authorities were proclaimed "Cominformists".

Most of them were imprisoned without trial; they were subjected to physical and psychological torture, just as the "real" Cominformists were; and many were censured. In the 1980s, some of the former prisoners wrote about how they had been treated (Janez Jezeršek, Martin Mencej, Radovan Hrast, Cene Logar, Jože Jurančič, Igor Torkar). Political opponents were deprived of freedom in one of two ways. The so-called administrative penalty was imposed directly by the State Security Administration (UDBA) without co-operation with the judicial system. UDBA had great power and could send a person to perform Community Service (CS) for a period of up to two years; this procedure could be repeated (the prisoner was released for a short time and later arrested again). The second way was sentencing performed by civil and military courts. In 1948,

5 See e.g. Vodušek Starič, Začetki samoupravljanja v, the chapter Nekaj o samoupravi med narodnoosvobodilno vojno in o razvoju leta $1945 v$ Sloveniji /A Few Words on Self-Management during the National Liberation War and on Development in Slovenia in 1945.

6 Pirjevec, Tito, Stalin in; Bilandžić, Historija SFRJ; Bekić, Jugoslavija u bladnom.

7 Petranović, Istorija Jugoslavije, p. 240.

8 Ibid., p. 288. 
not many arrests were made; the majority of Cominformists were imprisoned over the following two years. Dragotin Gustinčič was arrested even before the conflict and was labelled a Cominformist later in prison. ${ }^{9}$

A total of 731 people were arrested (members and non-members of all classes); 334 of them received administrative penalties (penalties of up to two years, with a possibility of them being reimposed, were imposed by the State Security Administration); while 157 of them were sentenced in court. Some of them never returned from serving their sentences. It has been estimated that there were a total of around 1,000 Cominformists in Slovenia, which was a much lower number than in other parts of Yugoslavia. ${ }^{10}$ The authorities mostly searched for Cominformists among the intellectuals, because they were the most critical of the government. In the mid-1950s, the passing of Cominform-related sentences ceased (with a few exceptions), but the authorities still kept a close eye on former prisoners and categorised them into four groups based on the "degree of their opposition". This categorisation was mostly a result of the renewed straining of Yugoslav-Soviet relations in 1956 (dissolution of the Cominform as the coordinating body of communist parties, riots in Poland, the intervention of the Red Army in Hungary). Since this straining was not as severe as the one in 1948, and because by then the situation in Yugoslavia had gradually democratised, the authorities set out to "re-educate" the Cominformists. For that reason, they were divided into categories; those in the first group could immediately rejoin the $\mathrm{CP}$, whereas the authorities considered those in the fourth group openly hostile (in 1958 there were 58 such people). At that time, Cominformism in reality no longer existed, neither as a Yugoslav nor as a Slovenian political problem, even though Cominformists were still under surveillance until the mid-1980s. At the beginning of the 1950s, the conflict with the Cominform was followed by a search for an alternative route to socialism.

Repression slowly began to abate: according to data from the Public Prosecutor's Office of the People's Republic of Slovenia there were 207 political convicts in Slovenia in 1952, and 91 in 1953 (between 1948 and 1950 around 1,000 people were convicted of political offences annually, which did not include the so-called administrative penalties. $)^{11}$ Most priests were released from prison and the authorities allowed the publication of the religious periodical Družina (Family) and the establishment of a seminary in Vipava (however, they excluded the Faculty of Theology from the University). Collectivisation was also abandoned (in 1954 there were only 43 agricultural working

9 Dragotin Gustinčič was pre-war communist, a member of the politburo of the Central Committee of the Communist Party, a participant in the debate on the national question in the party in 1920s and a supporter of federalism. He also fought in the Spanish Civil War. In the 1930s he lived mostly in Moscow. After the war, he was a university professor and he did not have a significant influence in CPS. He was arrested in 1948 and released in 1951. He served his sentence on Goli Otok.

10 Gabrič, Informbirojevstvo na Slovenskem, pp. 163-174.

11 Čepič et al., Ključne značilnosti slovenske politike, p. 104. 
cooperatives left in Slovenia; when collectivisation was at its peak, 8,600 farm holdings with 32,000 family members were included in 382 co-operatives). In the context of Slovenia, the new economic system introduced in the early 1950s denoted above all the freeing up of domestic trade and the modernisation of banking on more modern foundations (among other things, the introduction of the so-called communal banks that began conducting transactions with citizens, giving out housing loans, and providing other services to a limited extent). The new economic system also introduced significant changes to the supply of the population. In October 1951, the guaranteed supply system was abolished, coupons were replaced with money, and in the months to come, market prices were introduced for rationed goods. The supply of the population started to depend on the operation of commercial companies and on buyers' earnings. ${ }^{12}$ In 1952, the agitprop apparatus was abolished (it was revived in 1956 in a milder form as an ideological commission at the Central Committee of the League of Communists of Slovenia). Ideological control lessened, which resulted in the creation of a number of ideologically unburdened works in diverse areas of culture. (The most typical example of cultural relaxation in Slovenia is the "bourgeois" comedy film Vesna directed by František Čap). The relations relaxed after the border issues had been settled, following a severe straining of Yugoslav-Italian relations in 1953 (the signing of the so-called London Memorandum in 1954 and of the Austrian State Treaty in 1955). In 1955, Yugoslavia and Italy signed an agreement on border traffic, the so-called Udine Agreement, which was undoubtedly the first agreement of its kind between the two neighbouring countries after the Cold War. Slovenia had a specific position within Yugoslavia: bordering with Italy and Austria, and with strong national minorities in those countries, it was Yugoslavia's most developed and pro-West oriented region. Opening up the borders enabled people to make comparisons, and Slovenian authorities were forced - more than the authorities in other parts of Yugoslavia - to try to match the personal and social standard to those of the two neighbouring countries. Slovenian industry likewise - though slowly and awkwardly - kept up with the demands of buyers and in the mid-1950s began making refrigerators, washing machines and other household appliances and developing a more attractive textile industry, as well as other industries. Western influences in the post-Cominform period must be viewed within a wider context, together with Western films and music that started coming to these parts in the early 1950s, with the development of television in the late 1950s, and with the increase in motorisation, the number of foreign tourists and economic emigration (so-called gastarbajters - workers on temporary work abroad, who regularly returned for holidays, had deposits in Yugoslav banks, builthouses). The effects of this early liberalisation process were reflected in a gradual raising of the standard and in a faster path towards consumerism. Despite these

12 Prinčič, Vzačaranem krogu, p. 17. 
changes, nothing changed regarding the dominant role of the League of Communists in society, the ideology prevalent in all aspects of social life, and the supremacy of political elites over economic and other centres of power. But on the other hand, a blend of the socialist system and capitalists influences from the West created an unusual atmosphere. People did believe in Tito, self-management and the Non-Aligned Movement, but also in washing machines, refrigerators, TV sets and other elements of consumer society.

\section{Sources and literature}

Bekić, Darko, Jugoslavija u bladnom ratu/Yugoslavia in the Cold War. Zagreb: Globus, 1988. Bilandžić, Dušan, Historija SFRJ/History of the SFRY. Zagreb: Školska knjiga, 1985.

Čepič, Zdenko et. al., Ključne značilnosti slovenske politike v letih 1929-1955/Key Characteristics of Slovenian Politics in 1929-1955. Znanstveno poročilo. Ljubljana: Inštitut za novejšo zgodovino, 1995.

Dedijer, Vladimir, The Battle Stalin lost. Memoirs of Yugoslavia 1948-1953. [Nottingham]: Spokesman, [1978].

Gabrič, Aleš, Informbirojevstvo na Slovenskem/Cominformism in Slovenia. Prispevki za novejšo zgodovino XXXIII/1-2, 1993, pp. 163-174.

Lešnik, Avgust, Informbiro. Janez Cvirn (ed.), Ilustrirana zgodovina Slovencev/Illustrated history of Slovenes. Ljubljana: Mladinska knjiga, 1999.

Perović, Latinka, Dominantna i neželjena elita/Dominant and unwanted elite. Second ed. Beograd: Dan Graf; Novi Sad: Radio-televizija Vojvodine, 2016.

Petranović, Branko, Istorija Jugoslavije 1918-1988/History of Yugoslavia 1918-1988. Beograd: Nolit, 1989.

Pirjevec, Jože, Tito, Stalin in Zahod/Tito, Stalin and the West. Ljubljana: Delavska enotnost, 1987 (Italian edition in 1985).

Prinčič, Jože, $V$ začaranem krogu. Slovensko gospodarstvo od nove ekonomske politike do velike reforme 1955-1970/In a Vicious Circle. Slovenian Economy from the Nerw Economic Policy to the Great Reform 1955-1970. Ljubljana: Cankarjeva založba, 1999.

Repe, Božo, "Liberalizem" v Sloveniji/Liberalism in Slovenia. Ljubljana: RO ZZB NOV Slovenije, 1992.

Vodušek Starič, Jera, Začetki samoupravljanja v Sloveniji/Beginnings of Self-Management in Slovenia. Maribor: Obzorja, 1983. 


\title{
Summary
}

\author{
Božo Repe
}

\section{The Tito-Stalin Conflict: Yugoslavia as the Westernmost Part of the Eastern World}

In Slovenia, very few people openly supported the Cominform, which is why we cannot speak of an organised Cominform opposition. There was no danger of a "fifth column" in the event of a Soviet attack in contrast to the traditionally Russophile regions of Yugoslavia. Still, the lists of the State Security Administration (UDBA) contained the names of many people who criticised the authorities for various reasons. Because the term Cominformist had become a synonym for an internal enemy of the state, such critics of authorities were proclaimed "Cominformists". Most of them were imprisoned without trial; they were subjected to physical and psychological torture, just as the "real" Cominformists were. A total of 731 people were arrested (members and non-members of Party and from all social strata of the population). 334 of them received administrative penalties (penalties of up to two years, with a possibility of being reimposed, were imposed by the State Security Administration); while 157 of them were sentenced in court. Some of them never returned from serving their sentences. It has been estimated that there were a total of around 1,000 Cominformists in Slovenia, which was a much lower number than in other parts of Yugoslavia. The authorities mostly searched for Cominformists among the intellectuals, because they were most critical of the government. In the mid-1950s, the passing of Cominform-related sentences ceased, but the authorities still kept a close eye on former prisoners. In the early 1950s, the conflict with the Cominform was followed by a search for an alternative route to socialism. The League of Communists kept a dominant role in society, the ideology was prevalent at least in the main aspects of social life, and the supremacy of political elites over economic centres of power was evident until the end of Yugoslavia. But on the other hand, Yugoslavia opened its borders, and Western influence on everyday life was strong, with films, music, and literature, which started coming to these parts in the early 1950s. It also grew with the advent of television in the late 1950s, and with the increase in motorisation and the development of tourism. The effects of these early liberalisation processes were reflected in a gradual rising of the standard and in a faster path towards consumerism. 